\title{
Comparison of Enzymatic and Ultrasonic Extraction of Albumin from Defatted Pumpkin (Cucurbita pepo) Seed Powder
}

\author{
Gia Loi Tu, Thi Hoang Nga Bui, Thi Thu Tra Tran, Nu Minh Nguyet Ton and \\ Van Viet Man Le* \\ Department of Food Technology, Ho Chi Minh City University of Technology 268 Ly Thuong Kiet Street, \\ District 10, 70000 Ho Chi Minh City, Vietnam \\ Received: March 7, 2015 \\ Accepted: July 2, 2015
}

\begin{abstract}
Summary
In this study, ultrasound- and enzyme-assisted extractions of albumin (water-soluble protein group) from defatted pumpkin (Cucurbita pepo) seed powder were compared. Both advanced extraction techniques strongly increased the albumin yield in comparison with conventional extraction. The extraction rate was two times faster in the ultrasonic extraction than in the enzymatic extraction. However, the maximum albumin yield was $16 \%$ higher when using enzymatic extraction. Functional properties of the pumpkin seed albumin concentrates obtained using the enzymatic, ultrasonic and conventional methods were then evaluated. Use of hydrolase for degradation of cell wall of the plant material did not change the functional properties of the albumin concentrate in comparison with the conventional extraction. The ultrasonic extraction enhanced water-holding, oil-holding and emulsifying capacities of the pumpkin seed albumin concentrate, but slightly reduced the foaming capacity, and emulsion and foam stability.
\end{abstract}

Key words: albumin, Cucurbita pepo, extraction, functional properties, hydrolase, ultrasound

\section{Introduction}

Oilseeds and their agro-industrial residuals (defatted oil cakes) are cheap sources of proteins for human consumption. Besides the popular oilseeds including soya bean, rapeseed, cottonseed, sunflower seed, peanut and safflower seed (1), pumpkin seed is a potential source of edible proteins (2). Pumpkin seed contains four protein groups: alkali-soluble glutelin, salt-soluble globulin, water-soluble albumin and alcohol-soluble prolamin. Among them, glutelin and globulin are major protein groups, while albumin and prolamin were found in smaller amounts. Pumpkin seed proteins could be used in food processing as nutrient supplements and functional ingredients (3). In addition, pumpkin seed proteins showed different biological activities such as antibacterial, anti-inflammatory (4) and antioxidant activity (5).
Defatted oil cakes have been used in the production of protein concentrate and isolate. Protein extraction is performed and the extract obtained is used for protein purification and concentration. Extraction is a key operation in the production of protein preparations. Protein composition in the extract strongly depends on the nature of the used solvent (6). Previously, extraction of globulin, one of major proteins from defatted pumpkin seed powder, was performed with sodium chloride solution for preparation of protein concentrate (7). Nevertheless, extraction of other protein groups such as albumin has never been reported in the literature.

Oilseed albumin can be easily extracted with water an eco-friendly solvent. There have been few studies on albumin extraction from plant materials. Previous studies showed that albumin concentrate from African locust 
bean (8) or Gingko biloba (9) had good functional properties when added to food. To our knowledge, functional properties of pumpkin seed albumin have not been reported.

In the last decade, advanced techniques have been applied for protein extraction from plant materials. Use of hydrolase (10-12) or ultrasound (13-15) significantly improved the protein yield as well as reduced the extraction time in comparison with conventional extraction. However, comparison of enzyme- and ultrasound-assisted extractions of proteins from plant materials has never been reported.

The objective of this research is to compare the efficiency of the enzyme- and ultrasound-assisted extractions of albumin from defatted pumpkin seed, and to evaluate functional properties of albumin concentrates obtained using three methods: enzymatic, ultrasonic and conventional extraction.

\section{Materials and Methods}

\section{Materials}

Pumpkin (Cucurbita pepo) seeds were supplied from a pumpkin processing plant in Ho Chi Minh City, Vietnam. For preparation of defatted pumpkin seed powder, the seeds were first washed with potable water and the kernels were manually separated from the seeds. The kernels were then ground to particles of a size less than $10 \mathrm{~mm}$ and dried at $40{ }^{\circ} \mathrm{C}$ to a moisture content of $10 \%$. Lipids were extracted from the kernels with hexane under the following conditions: material and solvent ratio of $1: 10$ by mass, temperature of $40{ }^{\circ} \mathrm{C}$, and extraction time of $36 \mathrm{~h}$. After extraction, the solid phase was separated by centrifugation at $5000 \times g$, dried at $40{ }^{\circ} \mathrm{C}$ to a moisture content less than $10 \%$ and finally ground to particles of a size less than $1 \mathrm{~mm}$. The obtained powder was stored at $4{ }^{\circ} \mathrm{C}$ until use for albumin extraction. Chemical composition of the defatted pumpkin seed powder was as follows (in \% of dry mass $(\mathrm{dm})$ ): ash 9.5 , lipid 5.7 , protein 57.8 , total sugars 3.5 , starch 15.4 , cellulose 4.5 , hemicellulose 2.8 and pectin 0.9 .

Hydrolase preparation, Viscozyme L, originating from Aspergillus aculeatus, was purchased from Novozymes A/S (Bagsværd, Denmark). The preparation mainly contains endo- $\beta-1,3-$ and 1,4-glucanase; the catalytic activity was 100 fungal $\beta$-glucanase units per gram (FBG/g). One unit of FBG is the amount of enzyme preparation required for barley $\beta$-glucan hydrolysis to produce reducing carbohydrates corresponding to $1 \mu \mathrm{mol}$ of glucose per min (the reaction occurs at $30^{\circ} \mathrm{C}$ and $\mathrm{pH}=5.0$ for $30 \mathrm{~min}$ ). The optimal $\mathrm{pH}$ and temperature of the preparation are 3.3-5.5 and $25-55^{\circ} \mathrm{C}$, respectively (16).

Deionised water was used as solvent for albumin extraction. Protein standards and all chemicals used in electrophoretic analysis were purchased from GeneOn (Ludwigshafen am Rhein, Germany). Other chemicals used in this study were of analytical grade and purchased from Sigma-Aldrich (St. Louis, MO, USA).

\section{Enzymatic extraction of albumin from defatted pumpkin seed powder}

Each 250-mL Erlenmeyer flask contained $10 \mathrm{~g}$ of defatted pumpkin seed powder, $100 \mathrm{~mL}$ of deionised water (solvent) and a predetermined amount of Viscozyme L preparation. The flasks were put in a thermostatic incubator shaker (model Certomat ${ }^{\circledR}$ BS-1; B. Braun Biotech. International $\mathrm{GmbH}$, Melsungen, Germany) for albumin extraction. In this study, the enzymatic treatment of defatted pumpkin seed powder and the albumin extraction occurred simultaneously. The time of the enzymatic treatment was therefore the same as extraction time.

Different amounts of Viscozyme L were added to the samples: $0,1,2,3,4,5,6$ and 7 FBG per $g$ of dry mass. The $\mathrm{pH}$ of samples was not adjusted $(\mathrm{pH}=6.9)$ and all samples were incubated at $35^{\circ} \mathrm{C}$ and $200 \mathrm{rpm}$ for $30 \mathrm{~min}$.

Different incubation temperatures were used: 35,40 , $45,50,55$ and $60^{\circ} \mathrm{C}$. Viscozyme L was added to the samples at the amount of $5 \mathrm{FBU} / \mathrm{g}$. The $\mathrm{pH}$ of samples was not adjusted $(\mathrm{pH}=6.9)$. The mixing rate and incubation time were $200 \mathrm{rpm}$ and $30 \mathrm{~min}$, respectively.

The influence of $\mathrm{pH}$ on enzymatic albumin extraction was investigated at $\mathrm{pH}=4.0,4.5,5.0,5.5,6.0,6.5$ and 7.0. Viscozyme L was used at the amount of $5 \mathrm{FBU} / \mathrm{g}$. All samples were incubated at $50{ }^{\circ} \mathrm{C}$ and $200 \mathrm{rpm}$ for $30 \mathrm{~min}$.

Various extraction time intervals were used: 5, 10, 20, 30, 50, 60 and $90 \mathrm{~min}$. Other conditions were fixed: enzyme amount of $5 \mathrm{FBU} / \mathrm{g}$, temperature of $50{ }^{\circ} \mathrm{C}, \mathrm{pH}=5.0$, mixing rate of $200 \mathrm{rpm}$.

At the end of the incubation, all samples were centrifuged (model Sigma 3K30; Sartorius, Tagelswangen, Switzerland) at $5000 \times g$ and $20^{\circ} \mathrm{C}$ for $30 \mathrm{~min}$ to remove the solids. Globulin (salt-soluble protein) can be contaminated in the obtained supernatant since some minerals in the defatted pumpkin seed powder are extracted together with albumin. In order to remove globulin from the extract, the supernatant was adjusted to $\mathrm{pH}=7.0$ using $0.1 \mathrm{M}$ $\mathrm{NaOH}$ and then dialysed against distilled water. A molecular mass cut-off membrane of $6 \mathrm{kDa}$ (BioVision Inc., Milpitas, CA, USA) was used in dialysis. After the dialysis, the content of dialysis bag was centrifuged at $5000 \times g$ and $20{ }^{\circ} \mathrm{C}$ for $30 \mathrm{~min}$ to remove the solids and the supernatant was used for albumin quantification.

\section{Ultrasonic extraction of albumin from defatted pumpkin seed powder}

The ultrasonic extraction was also performed in 250-mL Erlenmeyer flasks containing $10 \mathrm{~g}$ of defatted pumpkin seed powder and $100 \mathrm{~mL}$ of deionised water (solvent). The extraction consisted of two steps. In the first step, the ultrasonic treatment was conducted using a horn-type ultrasonic probe with frequency of $20 \mathrm{kHz}$ (model VC 750; Sonics \& Materials Inc, Newtown, CT, USA). All Erlenmeyer flasks were put in a cooling water bath (model WPE45; Memmert GmbH+Co.KG, Schwabach, Germany) during the ultrasonic treatment and the sample temperature was always below $30^{\circ} \mathrm{C}$. In the second step, the additional extraction was performed at $30^{\circ} \mathrm{C}$ and $200 \mathrm{rpm}$, after which the Erlenmeyer flasks were transferred into a thermostatic shaker. The total extraction time was therefore the sum of both steps. 
The ultrasonic power levels were adjusted to $0,5,10$, 15,20 and $25 \mathrm{~W}$ per $\mathrm{g}$ of dry mass. The sonication time was $1 \mathrm{~min}$. After the sonication, the time of the additional extraction was $30 \mathrm{~min}$.

The used ultrasonic time was: 0, 1, 2, 3, 4 and 5 min. The selected ultrasonic power level was $20 \mathrm{~W} / \mathrm{g}$. After the ultrasonic treatment, the time of the additional extraction was fixed at $30 \mathrm{~min}$.

The ultrasonic power level and time were set at 20 $\mathrm{W} / \mathrm{g}$ and $3 \mathrm{~min}$, respectively. After the sonication, the time of the additional extraction was varied: $0,5,10,20,30,40$, 50,60 and $90 \mathrm{~min}$.

At the end of the extraction, all samples were treated in the same way as shown in the previous section.

\section{Comparison of enzymatic and ultrasonic extraction of albumin from defatted pumpkin seed powder}

In both extraction methods, the ratio of defatted pumpkin seed and deionised water was set at 1:10 by mass. In the enzyme-assisted extraction, the enzyme amount, $\mathrm{pH}$, temperature, mixing rate and extraction time were $5 \mathrm{FBG} / \mathrm{g}, 5.0,50{ }^{\circ} \mathrm{C}, 200 \mathrm{rpm}$ and $90 \mathrm{~min}$, respectively. In the ultrasound-assisted extraction, the sonication power and time were $20 \mathrm{~W} / \mathrm{g}$ and $3 \mathrm{~min}$, respectively, and the treatment was performed at the temperature below $30^{\circ} \mathrm{C}$. After the sonication, the additional extraction was carried out at $30^{\circ} \mathrm{C}$ and $200 \mathrm{rpm}$ for $90 \mathrm{~min}$. During the extraction, samples were taken for dialysis in order to remove dissolved globulin group before albumin quantification.

The first-order rate law was applied for determination of the extraction rate constant of albumin (17). The general first-order model was as follows:

$$
\left(\gamma_{\infty}-\gamma_{\mathrm{t}}\right) /\left(\gamma_{\infty}-\gamma_{\mathrm{w}}\right)=\mathrm{e}^{-\mathrm{kt}}
$$

where $\gamma_{\infty}$ is maximal protein concentration in the extract $(\mathrm{g} / \mathrm{L}), \gamma_{\mathrm{t}}$ is protein concentration in the extract $(\mathrm{g} / \mathrm{L})$ at a given extraction time $t(\mathrm{~min}), \gamma_{\mathrm{w}}$ is initial protein concentration in the extract $(\mathrm{g} / \mathrm{L})$ and $k$ is extraction rate constant $(\mathrm{g} /(\mathrm{L} \cdot \mathrm{min}))$.

Since $\gamma_{\mathrm{w}}=0$ when $t=0$, the first-order model can be written as follows:

$$
\left(\gamma_{\infty}-\gamma_{t}\right) / \gamma_{\infty}=\mathrm{e}^{-\mathrm{kt}}
$$

The integrated rate law for a first-order extraction under the boundary conditions from $t=0$ to the complete time of the extraction ( $\mathrm{min}$ ) and from $\gamma_{\mathrm{t}}=0$ to the final protein concentration in the extract can be written as follows:

$$
\mathrm{d}\left(\gamma_{\mathrm{t}}\right) / \mathrm{d} t=\mathrm{d}\left(\gamma_{\infty} \cdot\left(1-\mathrm{e}^{-\mathrm{kt}}\right)\right) / \mathrm{d} t
$$

and

$$
\mathrm{d}\left(\gamma_{\mathrm{t}}\right) / \mathrm{d} t=k \cdot \gamma_{\infty} \cdot \mathrm{e}^{-\mathrm{kt}}
$$

when $t=0$, initial extraction rate $v(\mathrm{~g} /(\mathrm{L} \cdot \mathrm{min}))$ can be defined as:

$$
v=k \cdot c_{\infty}
$$

The maximal albumin concentration in the extract $\gamma_{\infty}$ $(\mathrm{g} / \mathrm{L})$, initial extraction rate $v(\mathrm{~g} /(\mathrm{L} \cdot \mathrm{min}))$ and extraction rate constant $k(\mathrm{~g} /(\mathrm{L} \cdot \mathrm{min}))$ were determined using $\mathrm{R}$ software v. 3.1.0 (The R Project for Statistical Computing, Auckland, New Zealand).

\section{Preparation of albumin concentrate from defatted pumpkin seed powder}

The protein extracts obtained by the enzymatic and ultrasonic extractions were used for preparation of albumin concentrates. Conventional extraction was also performed as a control under the following conditions: ratio of defatted pumpkin seed powder and deionised water of $1: 10$ by mass, temperature of $30^{\circ} \mathrm{C}$, natural $\mathrm{pH}=6.9$, mixing rate of $200 \mathrm{rpm}$ and extraction time of $120 \mathrm{~min}$.

The extracts obtained by the three extraction methods were dialysed against distilled water to remove dissolved globulin. After globulin removal, the protein extract was sampled for determination of albumin profile and subsequently adjusted to $\mathrm{pI}=3.0$ using $0.1 \mathrm{M} \mathrm{HCl}$ for albumin coagulation. The solid phase was separated by centrifugation at $5000 \times g, 20^{\circ} \mathrm{C}$ and redissolved in deionised water. The procedure of albumin coagulation at that $\mathrm{pI}$ value was repeated twice to increase the protein ratio in the albumin concentrate. The obtained albumin concentrate was used for determination of protein content and different functional properties including water absorption, oil absorption, emulsifying, foaming and gelation capacities, and foam and emulsion stability.

\section{Analytical methods}

Total protein content in the defatted pumpkin seed powder and the extract was determined by Kjeldahl method (18). Albumin profile in the extract was analysed by electrophoresis on sodium dodecyl sulphate polyacrylamide gel (SDS-PAGE) according to the procedure of Laemmli (19).

Water absorption and oil absorption capacities were evaluated using the method described by Beuchat (20). Emulsifying capacity and emulsion stability were determined according to the method used by Pearce and Kinsella (21), with modifications, where the emulsifying capacity was determined by measuring the absorbance of the sample after homogenisation at the initial time, and the emulsion stability was calculated as follows:

$$
\text { Emulsion stability }=\left(A_{0} / \Delta A\right) \cdot \Delta t
$$

where $A_{0}$ is the absorbance of the emulsion immediately after homogenisation and $\Delta A$ is the reduction in absorbance at time interval $\Delta t$.

Foaming capacity and foam stability were evaluated using the method reported by Sze-Tao and Sathe (22). Gelation capacity was evaluated using the method described by Coffmann and Garcia (23).

Particle size distribution of the material at the end of the enzymatic and ultrasonic extractions was determined using a laser diffraction particle size distribution analyser (model LA 920; Horiba, Kyoto, Japan) according to the method described by Hong et al. (24). The particle size curve, particle mean size $\left(d_{4,3}\right)$ and values $d_{10}, d_{50}$ and $d_{90}$ were determined using LA-920 software (Horiba). Diameters $d_{10}, d_{50}$ and $d_{90}$ correspond to the values of particle 
diameter that are below 10, 50 and $90 \%$, respectively, of the particle diameter of the whole sample.

The albumin yield in the extract was calculated by the following formula:

$$
Y=\left(m_{\mathrm{a}}-m_{\mathrm{t}}\right) / m_{\mathrm{t}}
$$

where $Y$ is the albumin yield (\%), $m_{\mathrm{a}}$ is the total protein mass $(\mathrm{g})$ in the extract after the globulin removal by dialysis and $m_{\mathrm{t}}$ is the total protein mass $(\mathrm{g})$ in defatted pumpkin seed powder used in albumin extraction.

\section{Statistical analysis}

All experiments were performed in triplicate. The experimental results were expressed as mean value \pm standard deviation. Mean values were considered significantly different at $\mathrm{p}<0.05$. One-way analysis of variance was performed using the software Statgraphics Centurion XV (Statpoint Technologies, Inc, Warrenton, VA, USA).

\section{Results and Discussion}

\section{Enzymatic extraction of pumpkin seed albumin}

Fig. 1a shows that the control without the addition of Viscozyme L gave the lowest albumin yield (11.4\%). Enzymatic extraction significantly improved the albumin yield from defatted pumpkin seed powder. Similar observation was reported when Viscozyme $L$ was used for the extraction of proteins from defatted soya bean flour (25), oat bran (10), rice bran (11) and buckwheat bran (26). Ac-
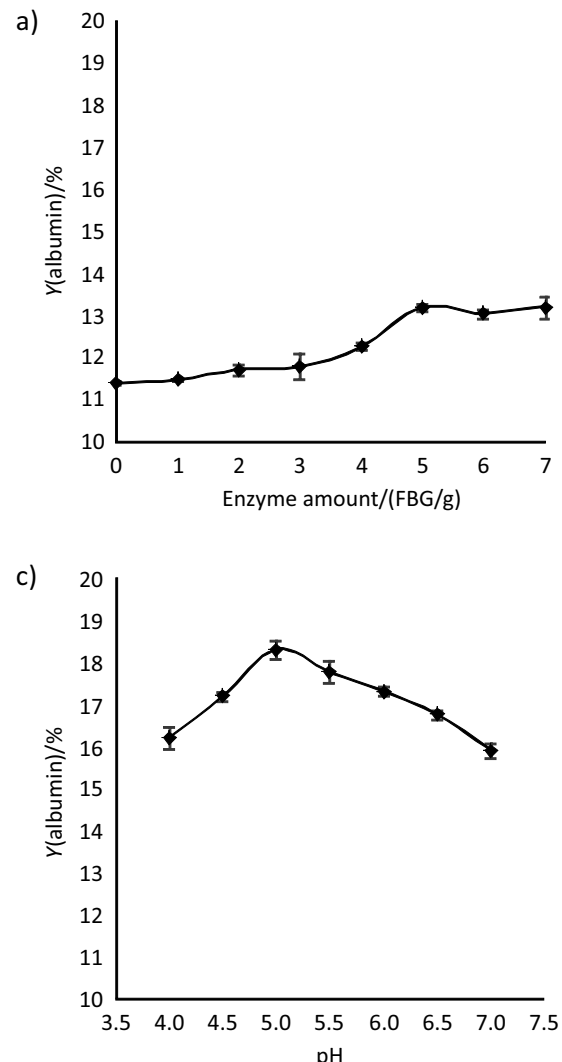

cording to Guan and Yao (10), endo- $\beta$-1,3- and 1,4-glucanase in the enzyme preparation degraded the cell wall of the plant material and enhanced protein release into the extract. In addition, hydrolysis of $\beta$-glucan reduced the viscosity and increased mass transfer during the protein extraction.

The higher the enzyme amount, the higher the albumin content in the extract. However, the increase in the amount of enzyme from 5 to 7 FBG/g did not increase the albumin yield. This finding was in agreement with that of Tang et al. (11) for the extraction of rice bran proteins.

The appropriate temperature and $\mathrm{pH}$ of the enzyme-assisted albumin extraction from defatted pumpkin seed powder were $50{ }^{\circ} \mathrm{C}$ and 5.0, respectively (Figs. $1 \mathrm{~b}$ and c). Other temperature and $\mathrm{pH}$ values resulted in similar or lower albumin content in the extract. The temperature of $50{ }^{\circ} \mathrm{C}$ and $\mathrm{pH}=5.0$ were conventionally used in biocatalysis with Viscozyme L (27).

Fig. 1d indicates that the albumin yield gradually augmented during the enzymatic treatment and achieved maximum at $60 \mathrm{~min}$. As mentioned above, the time of the enzymatic treatment in our study was the same as the extraction time. In some previous studies, when Viscozyme $\mathrm{L}$ was applied for protein extraction, the process consisted of two steps: enzymatic treatment of plant material at acidic $\mathrm{pH}$ and subsequent protein extraction at alkaline $\mathrm{pH}(10,25)$. The objective of these studies was to extract different protein groups including glutelins, an alkali-soluble protein group. The extraction time was consequently the sum of both steps. Guan and Yao (10) reported that
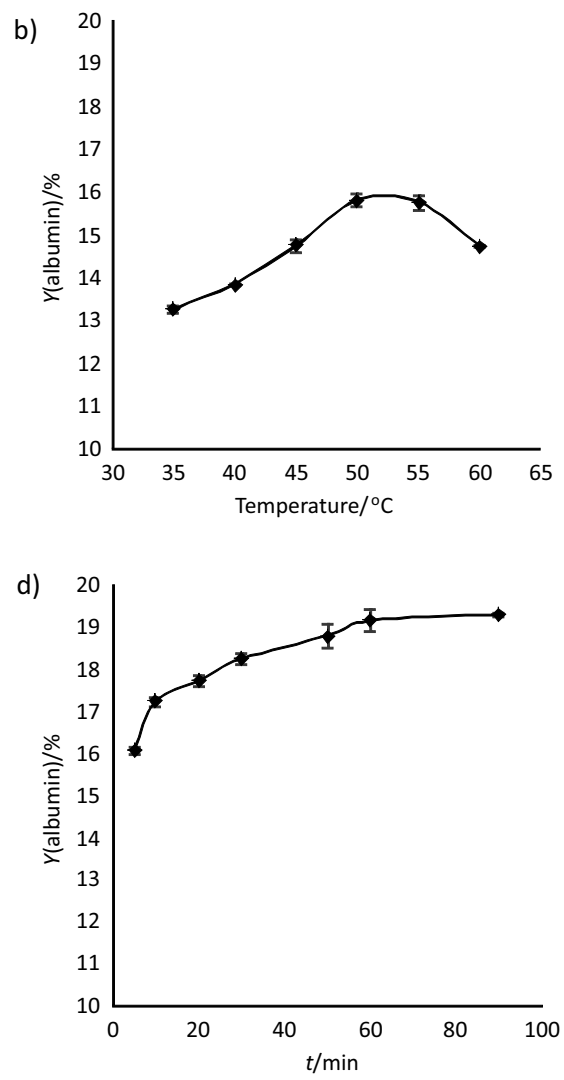

Fig. 1. Effects of: a) enzyme amount, b) temperature, c) $\mathrm{pH}$, and d) treatment time on the albumin yield. FBG=fungal $\beta$-glucanase unit 
the optimal time for the defatted oat bran treatment with Viscozyme $\mathrm{L}$ was $2.8 \mathrm{~h}$ and the subsequent protein extraction lasted for $0.5 \mathrm{~h}$; the total operation time was therefore 3.2 h. In a study of Rosset et al. (25), defatted soya flour was pretreated with Viscozyme L for $30 \mathrm{~min}$ and the following protein extraction was performed for $45 \mathrm{~min}$; the total time was therefore $75 \mathrm{~min}$. In our study, the combination of enzymatic treatment and albumin extraction in one step clearly reduced the operation time and simplified the operation performance.

The highest albumin yield in the extract was $19.1 \%$ at the enzyme amount of $5 \mathrm{FBG} / \mathrm{g}$, temperature of $50{ }^{\circ} \mathrm{C}$, $\mathrm{pH}=5.0$ and time of $60 \mathrm{~min}$. The yield in enzymatic extraction $(19.1 \%)$ was $68 \%$ higher than that in the conventional extraction (11.4\%). Improved protein extraction yield was reported when Viscozyme L was used. In protein extraction from soya flour, the protein yield increased $70 \%$ in comparison with that in the conventional extraction (25). However, the protein yield in the Viscozyme L-assisted extraction from oat bran was $281 \%$ higher than in the control (10). It should be noted that the extract contained different protein groups in the previous studies, while only albumin group was extracted in our study.

\section{Ultrasonic extraction of pumpkin seed albumin}

At low sonication power $(0-10 \mathrm{~W} / \mathrm{g})$, the ultrasound did not affect the albumin yield (Fig. 2a). Increase in sonication power from 10 to $25 \mathrm{~W} / \mathrm{g}$ significantly enhanced the albumin yield. In solid-liquid extraction, ultrasound caused cavitation, leading to the disruption of cell walls which resulted in great penetration of the solvent into cellular materials, improvement in mass transfer and improved release of cell content. High sonication power promoted intensive cavitation in the extraction system (28). As a result, the albumin yield was improved. Previously, Chittapalo and Noomhorm (15) also reported an increase in protein yield from defatted rice bran as a consequence of the increase in sonication power. However, Fig. 2a demonstrates that when the sonication power increased from 20 to $25 \mathrm{~W} / \mathrm{g}$, the albumin yield was slightly reduced. According to Barteri et al. (29), hydroxyl-free radicals produced by ultrasound promoted oxidation of cysteine residues; aggregation of protein molecules was therefore observed due to the formation of intermolecular disulphide bridges. In addition, the high sonication power generated strong shear forces which also resulted in protein denaturation (30). These phenomena reduced the content of soluble proteins in the extract.

Increase in sonication time from 0 to 3 min strongly improved the albumin yield; longer ultrasonic time significantly decreased the albumin yield (Fig. 2b). This result was different from the findings of Karki et al. (14). The longer the sonication time, the higher the protein yield from defatted soya bean powder; nevertheless, the maximum sonication time used in the study of Karki et al. (14) was only $2 \mathrm{~min}$. In the protein extraction from defatted rice bran, Chittapalo and Noomhorm (15) changed the sonication time from 0 to $40 \mathrm{~min}$; the protein yield gradually increased during the sonication and reduction in protein yield was not observed when the duration of sonication was prolonged. It should be noted that the maximum sonication power used in protein extraction from soya bean and rice bran powders was 12.8 and 5.0 $\mathrm{W} / \mathrm{g}$, respectively $(14,15)$. These values were significantly lower than that used in our study $(20 \mathrm{~W} / \mathrm{g})$. Prolonged acoustic cavitation at high ultrasonic power generated more hydroxyl-free radicals (31), which could denature soluble proteins in the extract and lead to a reduction in protein extraction yield.

With the selected sonication time of $3 \mathrm{~min}$, the albumin yield was $15.1 \%$ at the end of the ultrasonic treatment (Fig. 2c). The target compounds were not completely extracted during the sonication of defatted pumpkin seed powder. After the ultrasonic treatment, the additional extraction was essential for the improvement of the extracted albumin. The maximum albumin yield was $17.0 \%$ at the ultrasonic power of $20 \mathrm{~W} / \mathrm{g}$, sonication time of 3 min and additional extraction time of $40 \mathrm{~min}$. The ultrasonic extraction increased the albumin yield by $49 \%$ in comparison with the conventional extraction. Karki et al. (14) had previously noted that ultrasound increased the extraction yield of soya protein by $46 \%$ compared to the control.

\section{Comparison of enzyme- and ultrasound-assisted extractions of albumin from defatted pumpkin seed powder}

Changes in the albumin concentration in the extract during enzymatic and ultrasonic extractions are shown in Fig. 3. Based on the obtained results, the maximal albumin concentration in the extract $\left(\gamma_{\infty}\right)$, initial extraction rate
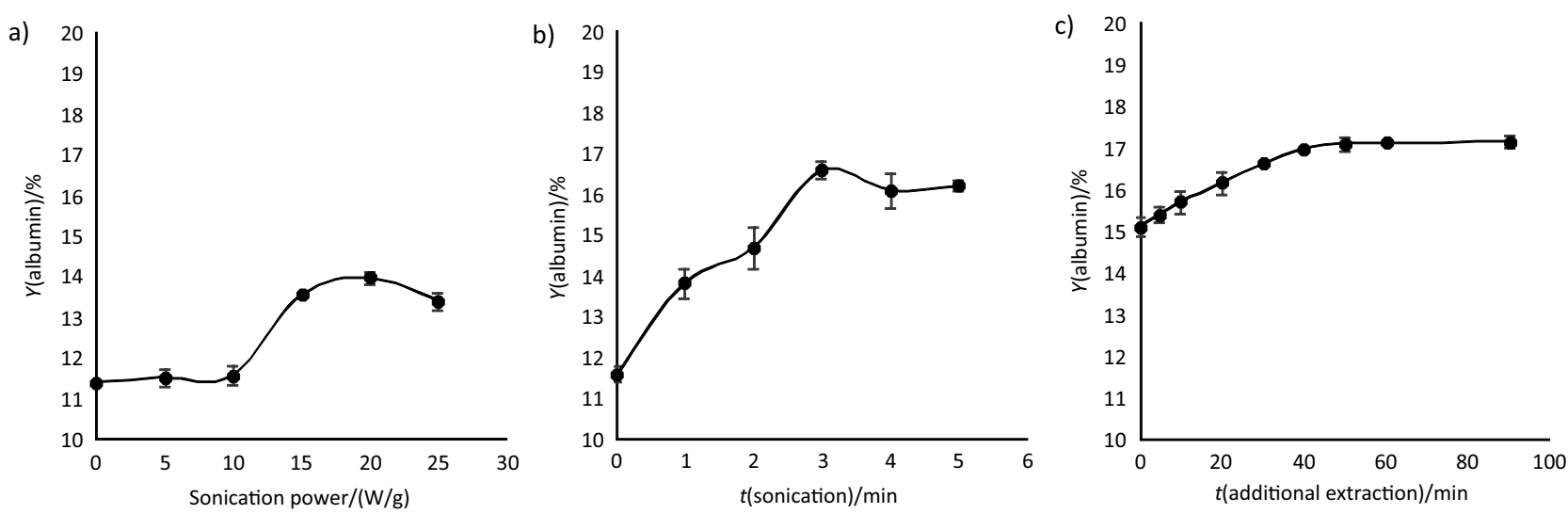

Fig. 2. Effects of: a) sonication power, b) sonication time, and c) additional extraction time on the albumin yield 


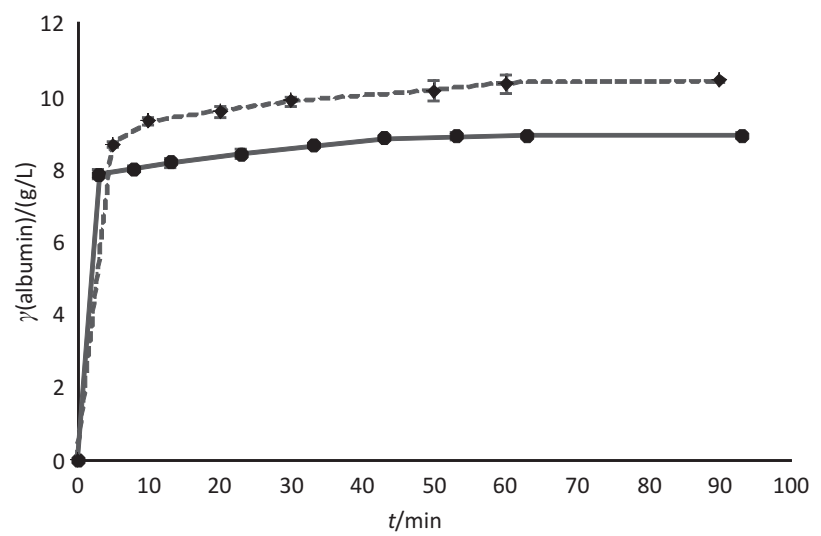

Fig. 3. Change in albumin concentration in the extract during: $(\bullet)$ enzymatic extraction, $(\bullet)$ ultrasonic extraction

$(v)$, extraction rate constant $(k)$ and coefficient of determination $\left(\mathrm{R}^{2}\right)$ were calculated.

Table 1 shows that the coefficient of determination $\left(\mathrm{R}^{2}\right)$ for both extraction methods was very high. Consequently, the first-order model described well our experimental results. Formerly, the first-order model was applied to ultrasonic extraction of proteins from rice bran (15). However, kinetic parameters of enzymatic extraction of proteins from plant materials have never been reported.

Table 1. Comparison of the first-order kinetic parameters of the enzymatic and ultrasonic extractions of albumin from defatted pumpkin seed powder

\begin{tabular}{ccccc}
\hline $\begin{array}{c}\text { Extraction } \\
\text { method }\end{array}$ & $\gamma_{\infty} /(\mathrm{g} / \mathrm{L})$ & $k /(\mathrm{g} /(\mathrm{L} \cdot \mathrm{min}))$ & $v / \mathrm{min}^{-1}$ & $\mathrm{R}^{2}$ \\
\hline Enzymatic & $(10.0 \pm 0.1)^{\mathrm{a}}$ & $(0.38 \pm 0.01)^{\mathrm{a}}$ & $3.12^{\mathrm{a}}$ & 0.996 \\
Ultrasonic & $(8.6 \pm 0.1)^{\mathrm{b}}$ & $(0.80 \pm 0.03)^{\mathrm{b}}$ & $1.56^{\mathrm{b}}$ & 0.993 \\
\hline
\end{tabular}

Values with different lower case letters in the same column are significantly different $(\mathrm{p}<0.05)$

The initial extraction rate $(v)$ and extraction rate constant $(k)$ in the ultrasonic extraction of albumin from defatted pumpkin seed powder were 2.0 and 2.1 times, respectively, higher than those in the enzymatic extraction. Higher extraction rate resulted in shorter extraction time. It was reported that ultrasound shortened the extraction time of grape juice over three times in comparison with enzyme-assisted extraction (32).

However, the ultrasonic extraction gave a lower albumin yield than the enzymatic extraction. The maximum albumin concentration in the extract $\left(\gamma_{\infty}\right)$ in the Viscozyme L-assisted method was $16 \%$ higher than that in the ultrasound-assisted method (Table 1). Comparison of particle size distribution of the solid phase at the end of enzyme- and ultrasound-assisted extractions has never been reported. Fig. 4 shows particle size distribution of the defatted pumpkin seed powder in the extraction system at the end of the process. The particle size in the enzymatic method (from 1 to $391 \mu \mathrm{m}$ ) varied less than in the ultrasonic method (from 1 to $517 \mu \mathrm{m}$ ). Table 2 demonstrates

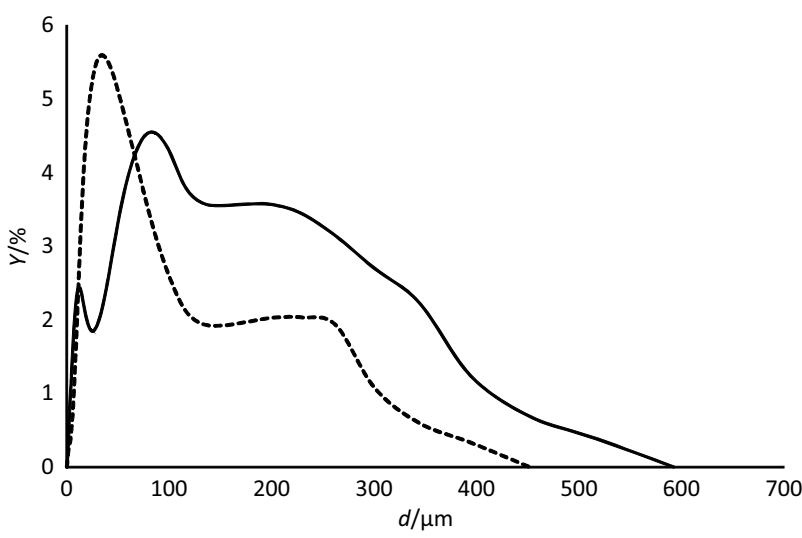

Fig. 4. Partical size $(d)$ distribution at the end of the extraction. Dashed line=enzymatic extraction, solid line=ultrasonic extraction. $Y=$ albumin yield

that values $d_{50}$ and $d_{90}$ in the enzymatic extraction were significantly lower than those in the ultrasonic extraction, while $d_{10}$ value was higher. In addition, the mean size $\left(d_{4,3}\right)$ of the material particles in the enzyme-assisted extraction $(58 \mu \mathrm{m})$ was lower than that in the ultrasound-assisted extraction $(90 \mu \mathrm{m})$. As a consequence, the enzymatic treatment of defatted pumpkin seed powder gave more uniform and smaller particle sizes than the ultrasonic treatment. It should be noted that Viscozyme L preparation used in this study contained multiple carbohydrate-degrading enzymes which can hydrolyse both cellulose and hemicellulose in the plant material and thus lead to an effective reduction in particle size of the pumpkin seed powder. Lower particle size of the plant material resulted in higher extraction yield.

Table 2. Particle size distribution of the solid phase at the end of the enzymatic and ultrasonic extractions of albumin from defatted pumpkin seed powder

\begin{tabular}{cccc}
\hline Extraction method & $d_{10} / \mu \mathrm{m}$ & $d_{50} / \mu \mathrm{m}$ & $d_{90} / \mu \mathrm{m}$ \\
\hline Enzymatic & $10^{\mathrm{a}}$ & $34^{\mathrm{a}}$ & $152^{\mathrm{a}}$ \\
Ultrasonic & $6^{\mathrm{b}}$ & $58^{\mathrm{b}}$ & $233^{\mathrm{b}}$ \\
\hline
\end{tabular}

Values with different lower case letters in the same column are significantly different $(\mathrm{p}<0.05)$

$d_{10}, d_{50}$ and $d_{90}=$ values of particle diameter that are below 10, 50 and $90 \%$, respectively, of the particle diameter or the whole sample

\section{Evaluation of functional properties of albumin obtained by different extraction methods}

The protein content in the albumin concentrates obtained using enzymatic, ultrasonic and conventional extractions was approx 80-82 \%. Fig. 5 shows the electrophoretic patterns of the three albumin concentrates under reducing conditions.

Similar bands were observed at 29 and $62 \mathrm{kDa}$, and in the ranges of 10.5-14, 22-29, 29-42, 42-51 and 51-62 kDa of the three samples. In addition, the albumin concentrates had a dark band with the molecular mass lower than 10.5 kDa. Previously, Rezig et al. (3) reported albumin bands in the range of 7-10 kDa extracted from Tuni- 


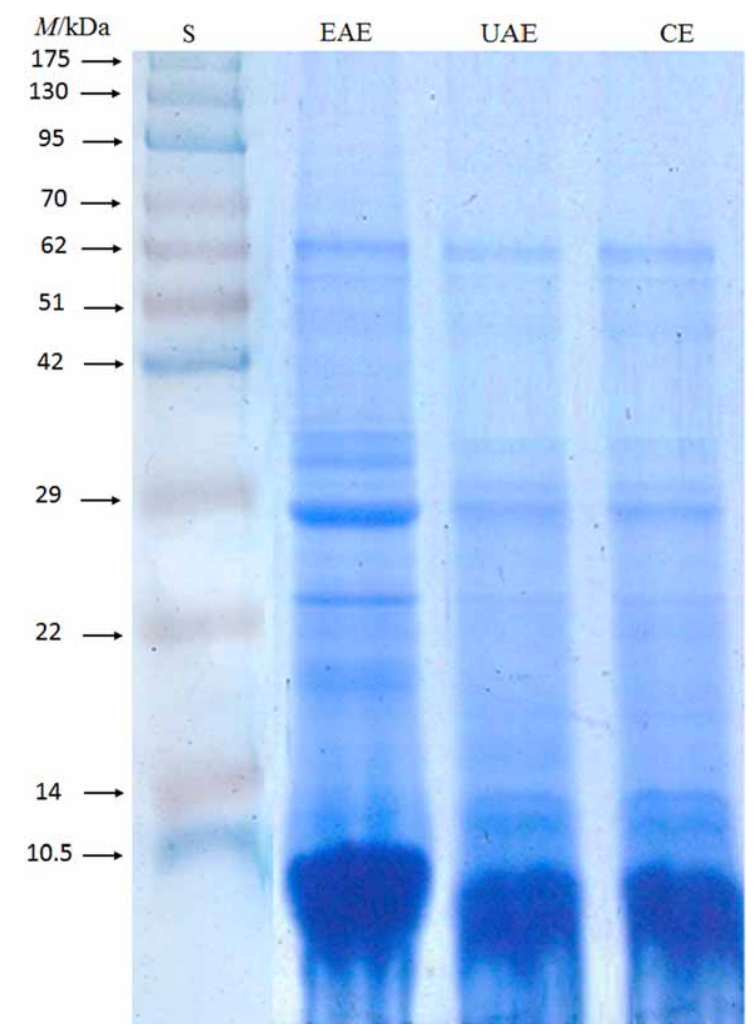

Fig. 5. Electrophoresis of albumin extracts using different extraction methods: $\mathrm{EAE}=$ enzyme-assisted extraction, $\mathrm{UAE}=$ ultrasound-assisted extraction, $\mathrm{CE}=$ conventional extraction, $\mathrm{S}=$ protein standards

sian pumpkin seed. However, the albumin profile in our study and that in the study of Rezig et al. (3) were different probably due to the difference in pumpkin varieties.

The albumin profiles (Fig. 5) from the ultrasonic and conventional extractions were similar. The enzyme-assisted extraction resulted in a new band in the range of 14-22 $\mathrm{kDa}$ in comparison with the ultrasound-assisted extraction. The explanation is that selective degradation of carbohydrates in plant cell wall by Viscozyme $\mathrm{L}$ and random breakdown of plant material by ultrasound can release different proteins into the extract.

Although a new protein band was observed in the extract obtained by enzymatic method, the functional properties of the albumin concentrate from both enzymatic and conventional extractions were similar (Table 3). The ultrasonic extraction changed the functional properties of the albumin preparation. Possible explanation is that shear forces and microstreaming generated from acoustic cavitation can change structural conformation of the extracted proteins. As a result, the obtained functional properties of the albumin concentrate were modified (28).

Interaction of water and oil with proteins affected the structure and flavour of food products (6). The ultrasonic extraction increased the water- and oil-holding capacity of the pumpkin seed albumin concentrate by 2.1 and 1.4 times, respectively, in comparison with the enzymatic extraction (Table 3). The water-holding capacity of pumpkin seed albumin concentrate was higher than that of the albumin concentrates from roselle seed $(0.74 \mathrm{~mL} / \mathrm{g})(33)$ and
Table 3. Functional properties of the albumin concentrates obtained by enzymatic, ultrasonic and conventional extractions from defatted pumpkin seed powder

\begin{tabular}{lccc}
\hline \multirow{2}{*}{ Functional property } & \multicolumn{3}{c}{ Extraction method } \\
\cline { 2 - 4 } & Enzymatic & Ultrasonic & Conventional \\
\hline $\mathrm{WAC} /(\mathrm{mL} / \mathrm{g})$ & $(1.13 \pm 0.04)^{\mathrm{b}}$ & $(2.50 \pm 0.07)^{\mathrm{a}}$ & $(1.19 \pm 0.03)^{\mathrm{b}}$ \\
$\mathrm{OAC} /(\mathrm{mL} / \mathrm{g})$ & $(2.6 \pm 0.1)^{\mathrm{b}}$ & $(3.7 \pm 0.1)^{\mathrm{a}}$ & $(2.44 \pm 0.03)^{\mathrm{b}}$ \\
Emulsifying capacity $(A)$ & $(0.23 \pm 0.02)^{\mathrm{b}}$ & $(0.41 \pm 0.04)^{\mathrm{a}}$ & $(0.24 \pm 0.01)^{\mathrm{b}}$ \\
Emulsion stability/min & $(16.3 \pm 0.1)^{\mathrm{b}}$ & $(15.1 \pm 0.1)^{\mathrm{a}}$ & $(16.3 \pm 0.2)^{\mathrm{b}}$ \\
Foaming capacity/\% & $(47.5 \pm 0.6)^{\mathrm{b}}$ & $(45.0 \pm 0.7)^{\mathrm{a}}$ & $(47.9 \pm 0.9)^{\mathrm{b}}$ \\
Foaming stability/\% & $(66.6 \pm 0.5)^{\mathrm{c}}$ & $(64.0 \pm 1.0)^{\mathrm{b}}$ & $(66.0 \pm 1.2)^{\mathrm{c}}$ \\
Gelation capacity/\% & $12^{\mathrm{b}}$ & $8^{\mathrm{a}}$ & $12^{\mathrm{b}}$ \\
\hline
\end{tabular}

Values with different lower case letters in the same row are significantly different $(\mathrm{p}<0.05)$.

WAC=water absorption capacity, $\mathrm{OAC}=$ oil absorption capacity, $A=$ absorbance of the sample at the initial time

Ginkgo seed (0.41 mL/g) (9). However, the pumpkin seed albumin concentrate had similar oil-holding capacity to the albumin concentrate from African locust bean (3.4 $\mathrm{mL} / \mathrm{g})(8)$.

The pumpkin seed albumin concentrate from ultrasound-assisted extraction showed better emulsifying capacity but slightly lower emulsifying stability than that from enzyme-assisted extraction. Previously, ultrasonic extraction was reported to decrease the emulsifying capacity and have no effect on emulsion stability of rice protein concentrate (15). Different results can be explained by different conditions of the ultrasonic treatment. Emulsification properties of proteins have been used in stabilization of food emulsions (6).

Proteins have also been used to stabilise foam in food systems such as some bakery products and sparkling drinks (6). The ultrasonic extraction slightly reduced foaming capacity and stability of the pumpkin seed albumin concentrate in comparison with the enzymatic extraction. Chittapalo and Noomhorm (15) reported a significant reduction in foaming capacity of the rice bran concentrate obtained by ultrasonic method.

The lower the concentration of protein concentrate in water for gelation, the better the gelation capacity. Ultrasound-assisted extraction improved gelation capacity of the pumpkin seed albumin concentrate more than the enzyme-assisted extraction. It was reported that ultrasound accelerated aggregation of egg white proteins in heat-induced gelation (34). In addition, ultrasonic treatment generated a firmer gel with enhanced water-holding properties and reduced gel syneresis (35).

\section{Conclusions}

Application of enzyme or ultrasound for albumin extraction from defatted pumpkin seed powder highly enhanced the albumin yield. The ultrasonic method needed shorter extraction time but gave lower albumin content in the extract than the enzymatic treatment. The enzyme-assisted extraction did not change water- and oil-holding, emulsifying, foaming and gelation capacity, or emulsion 
and foam stability of the albumin concentrate in comparison with the conventional extraction. However, the ultrasonic extraction improved some functional properties of the pumpkin seed albumin concentrate. Further study on enzymatic and ultrasonic extraction of albumin from defatted pumpkin seed powder on pilot scale is essential for the use of these advanced extraction methods in food processing.

\section{Acknowledgement}

This research was funded by Vietnam National Foundation for Science and Technology Development (NAFOSTED) under grant number 104.99-2013.74.

\section{References}

1. Moure A, Sineiro J, Domínguez H, Parajó JC. Functionality of oilseed protein products: a review. Food Res Int. 2006;39: 945-63.

http://dx.doi.org/10.1016/j.foodres.2006.07.002

2. El-Adawy TA, Taha KM. Characteristics and composition of watermelon, pumpkin, and paprika seed oils and flours. J Agric Food Chem. 2001;49:1253-9. http://dx.doi.org/10.1021/jf001117+

3. Rezig L, Chibani F, Chouaibi M, Dalgalarrondo M, Hessini K, Guéguen J, Hamdi S. Pumpkin (Cucurbita maxima) seed proteins: sequential extraction processing and fraction characterization. J Agric Food Chem. 2013;61:7715-21. http://dx.doi.org/10.1021/jf402323u

4. Fu CL, Huan S, Li QH. A review on pharmacological activities and utilization technologies of pumpkin. Plant Food Hum Nutr. 2006;61:73-80. http://dx.doi.org/10.1007/s11130-006-0016-6

5. Nkosi CZ, Opoku AR, Terblanche SE. Antioxidative effects of pumpkin seed (Cucurbita pepo) protein isolate in $\mathrm{CCl}_{4}-$ induced liver injury in low-protein fed rats. Phytother Res. 2006;20:935-40. http://dx.doi.org/10.1002/ptr.1977

6. Yada RY, editor. Proteins in food processing. Boca Raton, FL, USA: CRC Press; 2004.

7. Li QH, Fu C. Application of response surface methodology for extraction optimization of germinant pumpkin seeds protein. Food Chem. 2005;92:701-6. http://dx.doi.org/10.1016/j.foodchem.2004.08.042

8. Lawal OS, Adebowale KO, Ogunsanwo BM, Sosanwo OA, Bankole SA. On the functional properties of globulin and albumin protein fractions and flours of African locust bean (Parkia biglobossa). Food Chem. 2005;92:681-91. http://dx.doi.org/10.1016/j.foodchem.2004.08.043

9. Deng Q, Wang L, Wei F, Xie B, Huang FH, Huang W, et al. Functional properties of protein isolates, globulin and albumin extracted from Ginkgo biloba seeds. Food Chem. 2011; 124:1458-65.

http://dx.doi.org/10.1016/j.foodchem.2010.07.108

10. Guan X, Yao H. Optimization of Viscozyme L-assisted extraction of oat bran protein using response surface methodology. Food Chem. 2008;106:345-51. http://dx.doi.org/10.1016/j.foodchem.2007.05.041

11. Tang S, Hettiarachchy NS, Eswaranandam S, Crandall P. Protein extraction from heat-stabilized defatted rice bran: II. The role of amylase, celluclast, and viscozyme. J Food Sci. 2003;68:471-5. http://dx.doi.org/10.1111/j.1365-2621.2003.tb05696.x

12. Wang M, Hettiarachchy NS, Qi M, Burks W, Siebenmorgen T. Preparation and functional properties of rice bran protein isolate. J Agric Food Chem. 1999;47:411-6.

http://dx.doi.org/10.1021/j99806964

13. Zhu J, Fu Q, Optimization of ultrasound-assisted extraction process of perilla seed meal proteins. Food Sci Biotechnol. 2012;21:1701-6. http://dx.doi.org/10.1007/s10068-012-0226-7

14. Karki B, Lamsal BP, Jung S, van Leeuwen JH, Pometto III AL, Grewell D, Khanal SK. Enhancing protein and sugar release from defatted soy flakes using ultrasound technology. J Food Eng. 2010;96:270-8. http://dx.doi.org/10.1016/j.jfoodeng.2009.07.023

15. Chittapalo T, Noomhorm A. Ultrasonic assisted alkali extraction of protein from defatted rice bran and properties of the protein concentrates. Int J Food Sci Tech. 2009;44:1843-9. http://dx.doi.org/10.1111/j.1365-2621.2009.02009.x

16. Tabtabaei S, Diosady LL. Aqueous and enzymatic extraction processes for the production of food-grade proteins and industrial oil from dehulled yellow mustard flour. Food Res Int. 2013;52:547-56. http://dx.doi.org/10.1016/j.foodres.2013.03.005

17. Aguilera JM, Garcia HD, Protein extraction from lupin seeds: a mathematical model. Int J Food Sci Tech. 1989;24:17-27. http://dx.doi.org/10.1111/j.1365-2621.1989.tb00615.x

18. Latimer GW, editor. Official methods of analysis of AOAC International. Gaithersburg MD, USA: Association of Official Analytical Chemists (AOAC); 2012.

19. Laemmli UK. Cleavage of structural proteins during the assembly of the head of the bacteriophage T4. Nature. 1970; 227:680-5. http://dx.doi.org/10.1038/227680a0

20. Beuchat LR. Functional and electrophoretic characteristics of succinylated peanut flour protein. J Agric Food Chem. 1977; 25:258-61. http://dx.doi.org/10.1021/jf60210a044

21. Pearce KN, Kinsella JE, Emulsifying properties of proteins: evaluation of a turbidimetric technique. J Agric Food Chem. 1978;26:716-23. http://dx.doi.org/10.1021/jf60217a041

22. Sze-Tao KWC, Sathe SK, Functional properties and in vitro digestibility of almond (Prunus dulcis L.) protein isolate. Food Chem. 2000;69:153-60. http://dx.doi.org/10.1016/S0308-8146(99)00244-7

23. Coffmann CW, Garcia VV. Functional properties and amino acid content of a protein isolate from mung bean flour. Int J Food Sci Tech. 1977;12:473-84. http://dx.doi.org/10.1111/j.1365-2621.1977.tb00132.x

24. Hong K, Nakayama K, Park S. Effects of protective colloids on the preparation of poly(lactide)/poly(butylene succinate) microcapsules. Eur Polym J. 2002;38:305-11. http://dx.doi.org/10.1016/S0014-3057(01)00110-0

25. Rosset M, Acquaro Jr. VR, Beléia ADP. Protein extraction from defatted soybean flour with Viscozyme L pretreatment. J Food Process Preserv. 2014;38:784-90. http://dx.doi.org/10.1111/jfpp.12030

26. Grossman MV, Rao CS, Da Silva RSF. Extraction of proteins from buckwheat bran. J Food Biochem. 1980;4:181-8. http://dx.doi.org/10.1111/j.1745-4514.1980.tb00656.x

27. Singhania RR, Sukumaran RK, Patel AK, Larroche C, Pandey A. Advancement and comparative profiles in the production technologies using solid-state and submerged fermentation for microbial cellulases. Enzyme Microb Technol. 2010;46: $541-9$. http://dx.doi.org/10.1016/j.enzmictec.2010.03.010

28. Feng H, Barbosa-Cánovas GV, Weiss J, editors. Ultrasound technologies for food and bioprocessing. New York, USA: Springer; 2011. 
29. Barteri M, Diociaiuti M, Pala A, Rotella S. Low frequency ultrasound induces aggregation of porcine furmarase by free radicals production. Biophys Chem. 2004;111:35-42. http://dx.doi.org/10.1016/j.bpc.2004.04.002

30. Sotomayor M, Schulten K. Single-molecule experiments in vitro and in silico. Science. 2007;316:1144-8. http://dx.doi.org/10.1126/science.1137591

31. Ashokkumar M, Sunartio D, Kentish S, Mawson R, Simons L, Vilkhu K, Versteeg C. Modification of food ingredients by ultrasound to improve functionality: a preliminary study on a model system. Innov Food Sci Emerg Technol. 2008;9:15560. http://dx.doi.org/10.1016/j.ifset.2007.05.005

32. Lieu NL, Le VVM. Application of ultrasound in grape mash treatment in juice processing. Ultrason Sonochem. 2010;17:
273-9.

http://dx.doi.org/10.1016/j.ultsonch.2009.05.002

33. Tounkara F, Amza T, Lagnika C, Le GW, Shi YH. Extraction, characterization, nutritional and functional properties of roselle (Hibiscus sabdariffa Linn) seed proteins. Songklanakarin J Sci Technol. 2013;35:159-66.

34. Arzeni C, Pérez OE, Pilosof AMR. Functionality of egg white proteins as affected by high intensity ultrasound. Food Hydrocolloid. 2012;29:308-16.

http://dx.doi.org/10.1016/j.foodhyd.2012.03.009

35. Zisu B, Lee J, Chandrapala J, Bhaskaracharya R, Palmer M, Kentish S, Ashokkumar M. Effect of ultrasound on the physical and functional properties of reconstituted whey protein powders. J Dairy Res. 2011;78:226-32.

http://dx.doi.org/10.1017/S0022029911000070 